\section{Peptide Biocides for Engineering Bacterial Blight Tolerance and Susceptibility in Cut-flower Anthurium}

\author{
A.R. Kuehnle, ${ }^{1,6}$ T. Fujii,, ${ }^{1,3}$ F.C. Chen, ${ }^{1,4}$ A. Alvarez, ${ }^{2}$ N. Sugii, ${ }^{1,3}$ \\ R. Fukui, ${ }^{2,5}$ and S.L. Aragon ${ }^{1}$ \\ University of Hawaii at Manoa, 3190 Maile Way, Honolulu, HI 96822-2279
}

\author{
J.M. Jaynes ${ }^{6}$ \\ Department of Biological and Physical Sciences, 1000 Chastain Road \#1202 \\ Kennesaw State University, Kennesaw, GA 30144-5591
}

Additional index words. attacin, bioluminescence, lytic peptide, SB-37, Shiva-1, Xanthomonas axonopodis, Xanthomonas campestris

\begin{abstract}
Two cultivars of Anthurium andraeanum Hort. hybrids, 'Paradise Pink'and 'Tropic Flame', were transformed by Agrobacterium to contain gene sequences for Shiva-1, a cecropin-based lytic peptide. The antibacterial gene was driven by a 35-35S cauliflower mosaic viral (35-35S CaMV) promoter and the construct included the secretory signal sequence for pathogenesis-related protein 1b (PR1b). Blight tolerance of regenerated plants was tested by inoculation with a virulent strain of Xanthomonas axonopodis (formerly campestris) pv. dieffenbachiae $(\mathrm{Xad})$ that is bioluminescent to allow detection of symptomless infections in Shiva-1 transformants. Primary regenerants for two Shiva-1 transgenic lines of 'Paradise Pink' displayed significantly enhanced tolerance to bacterial blight over blight susceptible 'Rudolph' and even the blight tolerant 'Kalapana'. Two Shiva-1 transgenic lines of 'Tropic Flame' showed no improved resistance when compared to the control at the mean percent leaf infection level. One Shiva-1 transgenic line of 'Tropic Flame' was unexpectedly more susceptible to blight than the nontransgenic control. Low expression of Shiva-1 observed in this line is hypothesized to be the cause of its increased susceptibility to $\mathrm{Xad}$.
\end{abstract}

Anthurium blight caused by the bacterium Xanthomonas axonopodis (formerly campestris) pv. dieffenbachiae McCull \& Pirone $(\mathrm{Xad})$ has become a serious threat to the global anthurium industry, resulting in the devastation of many Caribbean and Pacific farms during the 1990s. Anthurium blight is also present in the Netherlands, a major exporter of anthurium cut flowers and leaves (Sathyanarayana et al., 1998). In Hawaii, which produces about one-fifth of the world's supply of cut flower anthurium, stringent sanitation and control practices have reduced the disease incidence, but infection persists in the field (Alvarez et al., 1989; Nishijima, 1988).

Received for publication 9 Sept. 2003. Accepted for publication 23 Dec. 2003. Journal series no. 4686 of the College of Tropical Agriculture and Human Resources. The authors thank T. Amore, N. Kuanprasert, R. Mudalige, H. Fukui and K. Chuang for assistance. This research was supported in part by the State of Hawaii Governor's Agricultural Coordinating Committee Grant 89-22 and the Hawaii Anthurium Industry Association.

${ }^{1}$ Department of Tropical Plant and Soil Sciences.

${ }^{2}$ Department of Plant and Environmental Protection Sciences.

${ }^{3}$ Current address: Harold L. Lyon Arboretum, University of Hawaii at Manoa, 3860 Manoa Rd., Honolulu, HI 96822.

${ }^{4}$ Current address: Dept. of Plant Industry, National Pingtung University of Science and Technology, Neipu, Pingtung 91201 Taiwan.

${ }^{5}$ Current address: Faculty of Agriculture, Utsunomiya University, Utsunomiya, Tochigi 321-8505 Japan.

${ }^{6}$ Towhom all correspondence should be addressed; e-mailheidi@hawaii.edu.
Eradication of $\mathrm{Xad}$ in the environment has proven difficult due to Hawaii's mild climate, the presence of alternative hosts, and use of symptomless infected propagative stock (Norman and Alvarez, 1996).

Genes encoding peptide biocides have held promise for engineering disease resistance into crops (Jaynes, 1993; Kuehnle et al., 1995). Of interest to us were two of the three classes of bactericidal proteins identified in the immunized pupae of the giant silkmoth, Hyalophora cecropia: attacins and cecropins (Boman et al., 1991). Attacins, at about $20 \mathrm{kDa}$, show activity against gram-negative bacteria by increasing the permeability of the bacterial outer membrane (Carlsson et al., 1991, 1998; Hultmark, 1993). Cecropins, small lytic peptides around $4 \mathrm{kDa}$, show high and broad potency against both gram-negative and gram-positive bacteria (Huang et al., 1997; Jaynes et al., 1987) by interfering with the inner and outer bacterial membranes (Boman, 1991). SB-37 and Shiva-1 are synthetic analogs of the natural cecropin $\mathrm{B}$, comprised of 38 amino acids and with similar or increased antibacterial activity (Jaynes et al., 1993).

We obtained transgenic anthurium plants of cultivar 'Rudolph' expressing attacin E while in the process of developing molecular breeding methods for anthurium using Agrobacterium tumefaciens Smith \& Townsend (Chen 1993; Chen and Kuehnle, 1996; Kuehnle et al., 2001). Plantlets showed significant absence or delay in disease symptom development and lower bacterial counts when analyzed by petiole challenge. At that time (pre-1993) no other group had yet reported antibacterial effectiveness of attacin in transgenic plants; only later were such reports published (Arce et al., 1999; Ko et al., 2000, 2002; Norelli etal., 1994; Reynoird etal., 1999). However, we chose to re-direct our efforts to testing of the cecropin analogue Shiva-1 due to its higher antibacterial activity in vitro against $\mathrm{Xad}\left(\mathrm{LD}_{100}\right.$ of $0.45 \mu \mathrm{M}$ attacin vs $0.3 \mu \mathrm{M}$ Shiva- 1 at $3 \times 10^{3} \mathrm{cfu} / \mathrm{mL} \mathrm{Xad} \cdot 150$ ) and a first report of Shiva-1 effectiveness in transgenic plants (Jaynes et al., 1993).

Disease resistance, delayed symptom expression or decreased plant mortality were observed in several model and crop plants bioengineered for the Shiva-1 or SB-37 lytic peptides when challenged with the major bacterial pathogens Ralstonia (formerly Pseudomonas) solanacearum Smith or Erwinia carotovora subsp. (Arce et al., 1999; Hassan et al., 1993; Jaynes et al., 1993). Our early work with anthurium produced 36 plants of selection 'UH1060' positive for SB-37 or Shiva-1 expression by reverse transcription polymerase chain reaction (RT-PCR) analysis, with thirteen (13\%) producing detectable levels of peptide. Four of the thirteen (31\%) peptide-positive plants showed disease attenuation not seen among 34 nontransgenic controls when sprayinoculated with $10^{4} \mathrm{cfu} / \mathrm{mL} \mathrm{Xad}$. in unreplicated trials (Kuehnle et al., 1996).

Here we report on bacterial blight tolerance tests for two commercial anthurium cultivars, 'Paradise Pink' and 'Tropic Flame', transgenic for Shiva-1 and tested in replicated disease trials. Results show that Shiva-1 significantly enhanced disease tolerance in one cultivar, but unexpectedly enhanced disease susceptibility in another.

\section{Materials and Methods}

Shiva-1 transgenics. 'Paradise Pink' (PP) is a heart-shaped blight susceptible cultivar and 'Tropic Flame' (TF) is a tulip-shaped blight susceptible cultivar (Kamemoto and Kuehnle, 1996). Plants transgenic for Shiva-1 were obtained using the $\mathrm{pBPRS} 1$ plasmid containing the PR1b secretion signal (Denecke et al., 1990) for Shiva-1 driven by a 35-35S CaMV promoter following the transformation protocol of Kuehnle et al. (2001). The process of Agrobacterium treatment, plant regeneration on selective medium, and molecular analysis by PCR and enzyme linked immunosorbant assay (ELISA) involved three genotypes and took 21 months due to the natural slow growth rate of anthurium. Plantlets expressing the lytic peptide were then selected for clonal micropropagation to establish lines of transformants for a 2-year period. Plants were hardened off in the greenhouse and transplanted to $15-\mathrm{cm}$ pots over the next 2 years. These plants were then rescreened by RT-PCR and northern analyses for Shiva-1 near the completion of the disease challenge.

Shiva-1 peptide quantification. Indirect competitive ELISA (Janssen, 1995) was used to estimate the levels of Shiva-1 peptide in transgenic plant tissue. Leaf samples were frozen in liquid nitrogen and ground in $10 x$ volume of phosphate buffered saline with tween $($ PBST $)+20 \%$ PVP-40 using chilled mortars and pestles. Shiva- 1 antigen, $25 \mathrm{ng}$, was bound 
to each well of a microtiter plate, incubated 5 to $6 \mathrm{~h}$ at $30^{\circ} \mathrm{C}$, then washed $3 \times$ with PBST. Each $75-\mu \mathrm{L}$ plant sample was mixed with $75 \mu \mathrm{L}$ of a antibody (diluted 1:10,000) and incubated for $1 \mathrm{~h}$ at room temperature. The sample-antibody mix was added to coated wells for overnight incubation at $4^{\circ} \mathrm{C}$. Plates were washed $3 \times$ with PBST. The antibody conjugate, goat anti-rabbit alkaline phosphatase (1:1000), $50 \mu \mathrm{L}$, was added to each well and incubated for 3-6 $\mathrm{h}$ at $30^{\circ} \mathrm{C}$. Plates were washed $3 \times$ with PBST. Seventy-five microliters p-nitrophenyl phosphate, $\left(1 \mathrm{mg} \cdot \mathrm{mL}^{-1}\right)$ substrate was added to each well, covered, and then incubated in the dark at room temperature. Plates were read on a BioRad ELISA plate reader at $\mathrm{OD}_{405}$ at $1,2,18$, and $24 \mathrm{~h}$. Standard curve samples, using peptide added to extracted wild-type plant sap of each genotype, were processed simultaneously with the transgenic tissues.

$P C R, R T-P C R$, and northern analysis for Shiva-1. DNA was extracted according to Dellaporta et al. (1983). PCR was performed using Shiva-1 primers 5'-TGCCATCCTTCTTTCTCGTG-3' and 5'-ATTCTCAACCAACTGCGCGG-3' that span essentially the entire coding region of Shiva-1, starting within the PR-1 signal peptide sequence, from position 26 to 214 on the gene (Kuehnle et al., 2001). The $\mathrm{PCR}$ reaction mix contained $2 \mathrm{~mm}$ magnesium chloride, $1 \times$ PCR buffer, $0.4 \mu \mathrm{M}$ of each primer, and $2.5 \mathrm{U}$ Taq polymerase in addition to the DNA. A BioRad iCycler was used employing an annealing temperature of $55^{\circ} \mathrm{C}$ for a total of 35 cycles. PCR bands were visualized on $1 \%$ w/v agarose gels using standard methods to confirm positives of the expected $188 \mathrm{bp}$ size. Transgenic samples were verified for transcript expression using RT-PCR. RNA was isolated from greenhouse-grown plants using either the CTAB method (Doyle and Doyle, 1990) or the method outlined in Aragon and Kuehnle
(2003). RT-PCR was initiated using $2 \mu \mathrm{g}$ total RNA according to a standard RT-PCR protocol from Sambrook and Russell (2001). PCR amplification using Shiva-1 PCR primers was performed and visualized as above.

Northern blots were used to further analyze anthurium plants that were positive for Shiva- 1 by ELISA, PCR, and RT-PCR. RNA samples were prepared (Aragon and Kuehnle, 2003) and total RNA was examined by electrophoresis in a $1.5 \% \mathrm{w} / \mathrm{v}$ denaturing agarose gel using the method outlined in Champagne and Kuehnle (2000). Total RNA, $15 \mu \mathrm{g}$, was loaded per lane for northern analysis. Blots were prepared following Sambrook and Russell (2001) and subsequently probed with a ${ }^{32}$ P-labeled Shiva-1 PCR-generated probe of 188 bp that encompasses the coding sequence of Shiva-1 with an expected RNA of about 340 bp, including the 3'-UTR and the poly(A) tail (Jaynes et al., 1993).

Bacterial challenge of Shiva-1 plants by spray-inoculation. Xanthomonas axonopodis pv. dieffenbachiae V108LRUH1 (Xad-lux), a bioluminescent strain, was used to monitor bacterial infection in leaves (Fukui et al., 1996). Bacterial inoculum was prepared (Fukui et al., 1996) and used at $10^{8} \mathrm{cfu} / \mathrm{mL} \mathrm{Xad} \cdot \mathrm{lux}$ or $10^{5}$ $\mathrm{cfu} / \mathrm{mL} \mathrm{Xad} \cdot \mathrm{lux}$ for spray-inoculation to run-off on every leaf; control plants were sprayed with sterile water. Plants were sealed in bags overnight at $23^{\circ} \mathrm{C}$, then grown under $70 \%$ shade in a greenhouse with hand-watering every other day. Average minimal and maximum temperatures were 23.9 and $31.6{ }^{\circ} \mathrm{C}$, conducive for blight development.

The luminescence of $\mathrm{Xad} \cdot \mathrm{lux}$ was used to monitor the internal progression of leaf infection to determine disease severity. Light produced by $\mathrm{Xad} \cdot$ lux was detected in a dark-

\section{$\begin{array}{lllll}3 & 4 & 5 & 6 & 7\end{array}$}

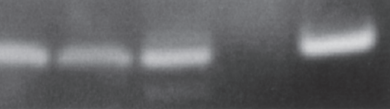

Fig. 1. RT-PCR analysis of a subset of transgenic Anthurium 'Paradise Pink' (PP) plants, selected from three different micropropagated transgenic lines prior to initial disease screening, using primers for the Shiva-1 transcript. Lane $1=\mathrm{PP}$ 1-1-1; Lane 2 = PP 1-1-2; Lane $3=$ PP 1-1-3; Lane $4=$ PP 1-2-1; Lane $5=$ PP 1-2-2; Lane 6 $=$ PP 1-5-1, known Shiva-1 negative control; Lane 7 = PP 1-5-2.

room using X-ray film, attached for 7 to $8 \mathrm{~h}$ to the two youngest fully open leaves (leaf 0 and leaf 1) of each plant, and the infection quantified by the area of exposed film (Fukui et al., 1996, 1998). Assessments of disease severity were performed at least three times up to 12 weeks postinoculation. Disease incidence was also recorded at each monitoring date as the number of replicated plants per line showing visual symptoms (water-soaking, necrosis) on the two leaves examined for bioluminescence. At 12 weeks postinoculation the percentage of all leaves showing visual symptoms and the total number of infection sites (based on three to four mature leaves per plant) were also recorded for plants treated with $10^{5} \mathrm{cfu} / \mathrm{mL}$ Xad.lux.

Five transgenic lines of 'Paradise Pink' (PP) and eight transgenic lines of 'Tropic Flame' (TF), six replicates each, were challenge-inoculated with $10^{8} \mathrm{cfu} / \mathrm{mL} \mathrm{Xad} \cdot \mathrm{lux}$ in a first trial. Lines PP 1-2,PP 1-4, TF 1-1, TF 1-9, and TF 1-16 were selected for a second bacterial challenge with $10^{5} \mathrm{cfu} / \mathrm{mL}$ Xad-lux. Each transgenic line as well as the nontransgenic TF control consisted of eight to ten plant replications in the second challenge. Nontransgenic 'Rudolph', with six

Table 1. Mean disease severity as percentage leaf infected of leaf 0 and leaf 1 of Anthurium 'Paradise Pink' (PP) transgenic lines, 'Rudolph', and 'Kalapana' inoculated with a bioluminescent strain of Xanthomonas axonopodis pv. dieffenbachiae at $10^{8} \mathrm{cfu} / \mathrm{mL}$. Means of six replicates of each line were not significantly different by Student Newman Keuls test at $P \leq 0.05$.

\begin{tabular}{|c|c|c|c|c|c|c|c|c|c|c|}
\hline \multirow[b]{2}{*}{ Plant line } & \multicolumn{2}{|c|}{ Week 4} & \multicolumn{2}{|c|}{ Week 6} & \multicolumn{2}{|c|}{ Week 7} & \multicolumn{2}{|c|}{ Week 9} & \multicolumn{2}{|c|}{ Week 12} \\
\hline & Leaf 0 & Leaf 1 & Leaf 0 & Leaf 1 & Leaf 0 & Leaf 1 & Leaf 0 & Leaf 1 & Leaf 0 & Leaf 1 \\
\hline PP 1-2 & 0.7 & 0.3 & 2.5 & 0.3 & 7.3 & 0.9 & 11.3 & 1.1 & 41.4 & 37.3 \\
\hline PP 1-6 & 0.7 & 0.3 & 1.4 & 1.2 & 4.3 & 2.5 & 9.1 & 4.9 & 32.6 & 31.0 \\
\hline Rudolph & 0.4 & 0.7 & 2.3 & 1.6 & 6.3 & 2.0 & 17.5 & 4.0 & 37.3 & 19.4 \\
\hline Kalapana & 0.3 & 0.5 & 1.4 & 0.9 & 2.4 & 4.7 & 4.9 & 1.0 & 14.2 & 18.3 \\
\hline
\end{tabular}

Table 2. Mean disease severity as a percentage of leaf infection and statistical ranking of control and Shiva-1 transgenic lines of anthuriums inoculated with a bioluminescent strain of Xanthomonas axonopodis pv. dieffenbachiae at $10^{5} \mathrm{cfu} / \mathrm{mL}$. Means of eight or ten replicates of 'Paradise Pink' (PP), seven replicates of 'Rudolph', and five replicates of 'Kalapana' with same letter in a column were not significantly different by Student Newman Keuls test at $P \leq 0.05$.

\begin{tabular}{|c|c|c|c|c|c|c|}
\hline \multirow[b]{2}{*}{ Plant line } & \multicolumn{2}{|c|}{ Week 6} & \multicolumn{2}{|c|}{ Week 8} & \multicolumn{2}{|c|}{ Week 12} \\
\hline & Infection (\%) & Ranking & Infection (\%) & Ranking & Infection (\%) & Ranking \\
\hline PP 1-2 & 0.5 & $14.3 \mathrm{a}$ & 0.8 & $12.7 \mathrm{~b}$ & 1.6 & $10.7 \mathrm{c}$ \\
\hline Rudolph & 5.4 & $17.9 \mathrm{a}$ & 20.7 & $24.7 \mathrm{a}$ & 95.7 & $26.0 \mathrm{a}$ \\
\hline \multicolumn{7}{|l|}{ Leaf 1} \\
\hline PP $1-2$ & 0.0 & $14.9 \mathrm{a}$ & 0.0 & $9.5 \mathrm{c}$ & 0.1 & $9.4 \mathrm{c}$ \\
\hline Rudolph & 11.8 & $18.4 \mathrm{a}$ & 37.0 & $22.3 \mathrm{a}$ & 100 & $24.5 \mathrm{a}$ \\
\hline
\end{tabular}


Table 3. Mean disease severity as percentage leaf infected of leaf 0 and leaf 1 of control and transgenic lines of Anthurium 'Tropic Flame' (TF) inoculated with a bioluminescent strain of Xanthomonas axonopodis pv. dieffenbachiae. Means of six replicates of each line were not significantly different by Student Newman Kuels test at $P \leq 0.05$

\begin{tabular}{lccrrr}
\hline & \multicolumn{2}{c}{ Week 8} & & \multicolumn{2}{c}{ Week 12 } \\
\cline { 2 - 3 } \cline { 5 - 6 } Plant line & Leaf 0 & Leaf 1 & & Leaf 0 & Leaf 1 \\
\hline TF 1-1 & 0.0 & 0.0 & & 0.0 & 0.4 \\
TF 1-4 & 0.1 & 0.4 & & 21.8 & 24.5 \\
TF 1-8 & 0.1 & 0.1 & & 0.6 & 0.0 \\
TF 1-9 & 0.2 & 0.3 & & 0.0 & 0.3 \\
TF 1-11 & 1.2 & 0.2 & & 8.2 & 2.9 \\
TF 1-13 & 4.2 & 0.0 & & 17.0 & 16.7 \\
TF 1-15 & 0.1 & 0.1 & & 16.7 & 16.7 \\
TF 1-16 & 4.3 & 0.4 & & 37.3 & 33.3 \\
TF control & 0.2 & 3.1 & & 0.2 & 3.5 \\
\hline
\end{tabular}

to seven replicates, was substituted for PP susceptible controls since PP plants of comparable size were unavailable at the time of inoculation; 'Rudolph' later was shown to be equivalent to PPin disease progression (see Results). Cultivar 'Kalapana', with five to six replicates, was included as a blight tolerant (Fukui et al., 1998) reference line. 'Kalapana' can develop foliar blight but rarely goes systemic in the grower's field. 'Paradise Pink' and 'Rudolph' typically develop foliar symptoms of water-soaked and necrotic spots, starting at the leaf margin due to entry at the hydathodes, followed by systemic infection leading to a yellowing of entire leaf blades, stem rot, and plant wilting. TF symptoms include a more pronounced localized necrosis of leaves before systemic infection.

Statistical analysis. Statistical analysis for disease severity based on bioluminescence of $\mathrm{PP}$ and TF plants was performed using percent infection data from leaf 0 and leaf 1 . Mean values of the five to ten replications for each anthurium line were subjected to analysis of variance using the nonparametric general linear model (RANK) of SAS (SAS Institute, Cary, N.C.). The RANK procedure assigned rankings to the percentage data and the rankings were subjected to analysis of variance. Mean rankings were separated by the Student-Newman-Keuls (SNK) test.

\section{Results}

Challenge-inoculation of Shiva-1 transformants. Results from PCR, ELISA, and RT-PCR performed on clones over a period of several years indicated that all anthurium lines propa- gated for disease challenge stably maintained the Shiva-1 insertedDNA and expressed the Shiva-1 transcript, with an expected RT-PCR amplified band size of about $200 \mathrm{bp}$ (Fig. 1). Towards the end of the final challenge experiment, blighted plants from all five transgenic lines of interest were again analyzed for Shiva-1 expression. Northern blots showed a single band at about $340 \mathrm{bp}$ for all transgenic plants examined, regardless of their disease susceptibility (Fig. 2). There was no band detected for nontransgenic TF and PP plants.

Peptide levels were measured in the original mother stock plants at the onset of micropropagation. Shiva-1 concentrations were $0.19,0.38$, and $0.16 \mu \mathrm{M}$ for TF 1-1, TF 1-9 and TF 1-16, respectively. Peptide concentrations were 0.13 and $0.06 \mu \mathrm{M}$ for PP 1-2 and PP 1-4, respectively. Our estimates of Shiva-1 peptide may be considerably lower than what is actually in the transgenic plants, due to the use of leaf extracts in the assay system and the lack of any protease inhibitor to reduce degradation of Shiva- 1 by the plant sap (Florack et al., 1995). Li et al. (2001) showed that mixing leaf extracts with Shiva-1 peptide standards reduced the quantity of peptide by as much as 50-fold, presumably due to protease activity in the leaf extracts. An adjustment of 50-fold increases the values for transgenic anthurium ( 8 to $19 \mu \mathrm{M}$ for 'Tropic Flame'; 3 to $6.5 \mu \mathrm{M}$ for 'Paradise Pink') to well within the range detected by Li et al. (2001) in transgenic grapevine leaves (5.7 to $15 \mu \mathrm{M})$.

'Paradise Pink' inoculated with $10^{8} \mathrm{cfu} / \mathrm{mL}$ $X a d \cdot l u x$. Leaf infection was monitored at 4, 6, 7, 9 , and 12 weeks postinoculation for transgenic lines and controls 'Kalapana' and 'Rudolph'. At four weeks postinoculation all lines displayed foliar symptoms and by week 12 all lines including the resistant check 'Kalapana'were systemically infected. However, 'Kalapana' consistently had the lowest disease severity in leaf 0 and leaf 1 at all monitoring dates (Table 1). According to the analysis of variance, the effects of plant line on disease severity (assessment of leaf 0 and leaf 1) at all dates were not significantly different at $P \leq 0.05$. However, when symptoms in leaf 1 were evaluated over time, disease seemed to progress slower among transgenic lines in PP 1-2 and PP 1-4 from 4 to 9 weeks postinoculation under such high inoculum. These two lines were selected for a second bacterial challenge using lower inoculum levels.

'Paradise Pink' inoculated with $10^{5} \mathrm{cfu} / \mathrm{mL}$ Xad.lux. At 6 weeks postinoculation, rank- ings of disease severity were not significantly different at $P \leq 0.05$ among all lines (Table 2). At 8 weeks, infection advanced markedly in 'Rudolph' and was significantly higher in 'Rudolph' leaf 0 (21\%) than in the other lines $(P>\mathrm{F}=0.0006)$. At 12 weeks, the last monitoring date, transgenic 'Paradise Pink' plants displayed equal or higher tolerance to $\mathrm{Xad} \cdot \mathrm{lux}$ than the blight tolerant 'Kalapana' and much higher tolerance than the blight susceptible 'Rudolph' (Table 2). Blight symptoms on the evaluated leaves matched the bioluminescent data, with symptoms on only 1 of 10 plants to 3 of 10 plants of PP 1-2 and PP 1-4 compared to 4 of 5 plants to 7 of 7 plants of 'Rudolph' and 'Kalapana' replicate plants. No significant difference in disease tolerance was determined between PP 1-2 and PP 1-4. Once 'Paradise Pink' plants of adequate size were available, 'Rudolph' was subsequently confirmed as an equivalent susceptible control. Results at 12 weeks postinoculation with $\mathrm{Xad}$-lux showed infection in 4 of $5 \mathrm{PP}$ plants with $35 \%$ to $75 \%$ disease severity and in 5 of 5 'Rudolph' plants with $3 \%$ to $100 \%$ disease severity.

'Tropic Flame' inoculated with $10^{8} \mathrm{cfu} / \mathrm{mL}$ Xad.lux. Leaf infection was monitored at 6 , 8 and 12 weeks postinoculation. At 6 weeks postinoculation no disease was detected by bioluminescence in any of the anthurium lines. At 8 and 12 weeks symptoms were detectable although disease severity was not significantly different $(P \leq 0.05)$ among the lines (Table 3$)$. When disease progression in leaf 0 and leaf 1 was examined, three transgenic lines, TF 1-1, TF 1-8, and TF 1-9, seemed to show delayed symptom development compared to the other transgenic lines. TF 1-1 and TF 1-9 were selected for a second challenge under lower inoculum levels along with TF 1-16, a line showing the greatest symptoms at week 12 (Table 3 ). Clonal plants of TF 1-8 were unavailable for a second challenge.

'Tropic Flame' inoculated with $10^{5} \mathrm{cfu} / \mathrm{mL}$ Xad.lux. At 6 weeks postinoculation, disease severity in TF 1-16 leaf 0 (4\%) was already significantly higher $(P>\mathrm{F}=0.0028)$ than the other transgenic lines and the control $(0 \%$ to $1.7 \%$; Table 4). A high percentage of $\mathrm{TF}$ 1-16 plants displayed blight symptoms (leaf $0,67 \%$ and leaf $1,56 \%$ ) compared to TF $1-1$ (both leaves 0\%), TF 1-9 (leaf 0, 20\% and leaf 1, 40\%), and TF control (both leaves 10\%). Trends toward increased disease severity and disease incidence in TF 1-16 continued through

Table 4. Mean disease severity as a percentage leaf infection and statistical ranking of control and Shiva-1 transgenic lines of Anthurium 'Tropic Flame' (TF) inoculated with a bioluminescent strain of Xanthomonas axonopodis pv. dieffenbachiae at $10^{5} \mathrm{cfu} / \mathrm{mL}$. Means of nine or ten replications with same letter in a column were not significantly different by Student Newman Keuls test at $P \leq 0.05$.

\begin{tabular}{|c|c|c|c|c|c|c|}
\hline \multirow[b]{2}{*}{ Plant line } & \multicolumn{2}{|c|}{ Week 6} & \multicolumn{2}{|c|}{ Week 8} & \multicolumn{2}{|c|}{ Week 12} \\
\hline & Infection (\%) & Ranking & Infection (\%) & Ranking & Infection (\%) & Ranking \\
\hline \multicolumn{7}{|l|}{ Leaf 0} \\
\hline TF $1-1$ & 0.0 & $15.5 \mathrm{~b}$ & 0.0 & $15.0 \mathrm{~b}$ & 0.0 & $13.5 \mathrm{~b}$ \\
\hline TF 1-9 & 1.7 & $19.5 \mathrm{~b}$ & 5.4 & $18.8 \mathrm{~b}$ & 12.8 & $18.2 \mathrm{~b}$ \\
\hline TF $1-16$ & 4.0 & $28.3 \mathrm{a}$ & 15.0 & $29.3 \mathrm{a}$ & 44.7 & $29.2 \mathrm{a}$ \\
\hline TF control & 0.9 & $17.6 \mathrm{~b}$ & 1.5 & $16.9 \mathrm{~b}$ & 4.9 & $17.9 \mathrm{~b}$ \\
\hline \multicolumn{7}{|l|}{ Leaf 1} \\
\hline TF 1-1 & 0.0 & $15.0 \mathrm{~b}$ & 0.0 & $14.5 \mathrm{~b}$ & 0.2 & $16.0 \mathrm{~b}$ \\
\hline TF $1-9$ & 1.3 & $21.8 \mathrm{ab}$ & 3.0 & $16.7 \mathrm{~b}$ & 4.8 & $16.7 \mathrm{~b}$ \\
\hline TF $1-16$ & 5.6 & $26.6 \mathrm{a}$ & 14.6 & $26.1 \mathrm{a}$ & 40.8 & $28.8 \mathrm{a}$ \\
\hline TF control & 1.5 & $17.3 \mathrm{~b}$ & 4.1 & $20.9 \mathrm{~b}$ & 5.5 & $19.5 \mathrm{~b}$ \\
\hline
\end{tabular}




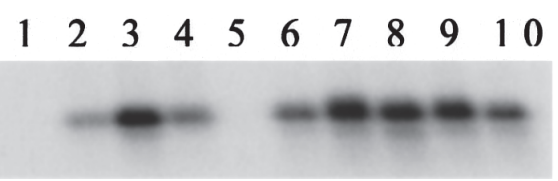

Fig. 2. Northern blot of total RNA extracted from Anthurium and visualized using a 32 -labeled Shiva-1 probe. Lanes correspond to those in Fig. 3. Lane 1 = 'Tropic Flame' (TF) wild-type; Lane 2 = TF 1-1-4; Lane $3=\mathrm{TF}$ 1-9-7; Lane 4 = TF 1-16-3, Lane $5=$ 'Paradise Pink' (PP) wild-type; Lane 6 = PP 1-4-2; Lane 7 = PP 1-4-9; Lane 8 = PP 1-2-9; Lane 9 = PP 1-2-10; Lane $10=$ PP 1-2-4
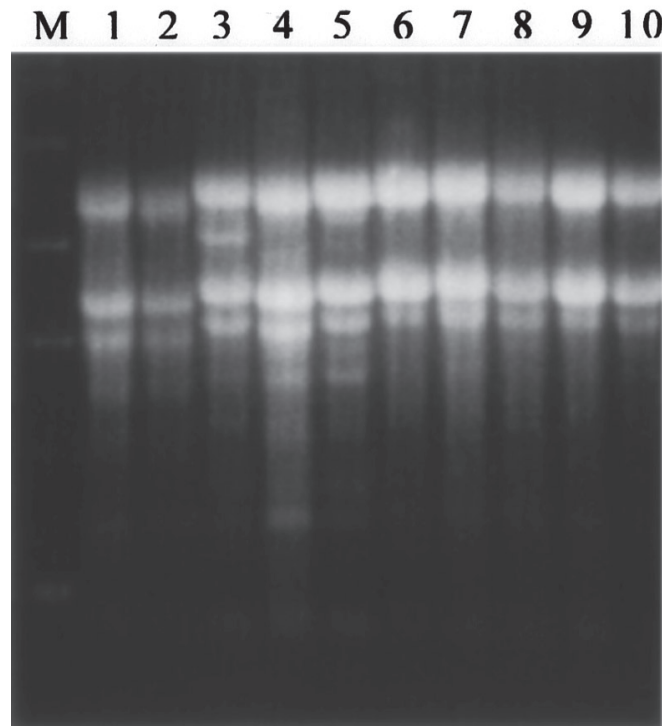

\section{$\sim 340 \mathrm{bp}$}

the two subsequent monitoring dates.

At 12 weeks postinoculasignificantly higher $(P>\mathrm{F}=0.0005$, leaf 0 and $P>\mathrm{F}=0.0038$, leaf 1$)$ than the other TF lines at $0 \%$ to $13 \%$ (Table 4 ). Disease incidence in TF $1-16$ reached a high of $78 \%$ of the plants for leaf 0 and $67 \%$ of the plants for leaf 1 , up from $67 \%$ and $56 \%$, respectively at week 8 . Disease incidence remained modest in the TF control for leaf 0 at $20 \%$ and leaf 1 at $40 \%$, up from $10 \%$ or unchanged from week 8 ; it remained low and unchanged over time for both transgenic lines (TF 1-1 leaf $0,0 \%$ and leaf $1,10 \%$; TF $1-9$, leaf $0,20 \%$ and leaf $1,10 \%$ ).

Bioluminescence data from $28 \mathrm{~S}$ all sampled leaves shows that TF 1-16 had enhanced susceptibility to blight over the control and the two other Shiva-1 transgenic lines. There was no difference in blight response among $\mathrm{TF}$ 1-1, TF 1-9, and the control. In a lane-by-lane comparison of northern results, TF 1-16 had much lower Shiva-1 expression than TF 1-9 (Fig. 2, lanes 3 and 4). A comparison of the $18 \mathrm{~S}$ RNA bands on the RNA gel reveals that the lane for TF 1-16 actually contains more total RNA loaded than TF 1-9 (Fig. 3, lanes 3 and 4). The lower amount of RNA loaded for TF 1-1 (Fig. 3, lane 2) compared to TF 1-9 (Fig. 3 , lane 3 ) explains the slightly weaker band for that transgenic line. These results were repeated in subsequent northern analysis (data not shown).

Representative X-ray films of inoculated leaves are shown in Fig. 4. Xad $\cdot$ lux was already heavily systemic by week 6 in the susceptible check 'Rudolph' (Fig. 4B) and in transgenic TF 1-16 (Fig. 4C) as seen by the black regions on bioluminescence-exposed film. Infection was only marginal in transgenic PP1-4 (Fig. 4A) or at the beginning stage of vascular entry in TF wild-type (Fig. 4D).

\section{Discussion}

In this study we adopted a nondestructive means (bacterial bioluminescence) to assess and quantify disease progression in transgenic plants. This assured that infected plants which harbored high bacterial counts yet remained symptomless (i.e., those with latent infection) did not escape detection. Using this means of assessment, transgenic 'Paradise Pink' displayed significantly enhanced tolerance to bacterial blight at an inoculum level that may be found in aerosols in the field. Although complete resistance was not obtained, a blight tolerance level that exceeds that of a "resistant" industry standard such as 'Kalapana' is nevertheless meaningful under field conditions. We intend to combine engineered tolerance with use of beneficial bacteria (Fujii et al., 2002; Fukui et al., 1999) to further reduce the plant inoculum levels in the field in an effort to maximize protection against bacterial blight for this perennial crop. Moreover, peptide quantification showed that the transgenic 'Paradise Pink' lines produced less Shiva-1 relative to 'Tropic Flame' lines, which did not display enhanced tolerance to blight. Secretion of the peptide into intercellular spaces was not determined. Nevertheless, these results may indicate that different genotypes of the same crop require different amounts of Shiva- 1 to have a measurable effect on enhancing blight tolerance. Different crops have already been shown to vary in their degradation of lytic peptides by intercellular fluids (Owens and Heutte, 1997; Sharma et al., 2000). This variation is thought to account for the failed resistance in transgenic tobacco (Florack et al., 1995; Hightower et al., 1994).

Bioluminescence data from 'Tropic Flame' showed that at least one transgenic line, TF 116 , had enhanced susceptibility to blight over the wild-type control. Disease onset was swift and bacteria proliferated much more rapidly

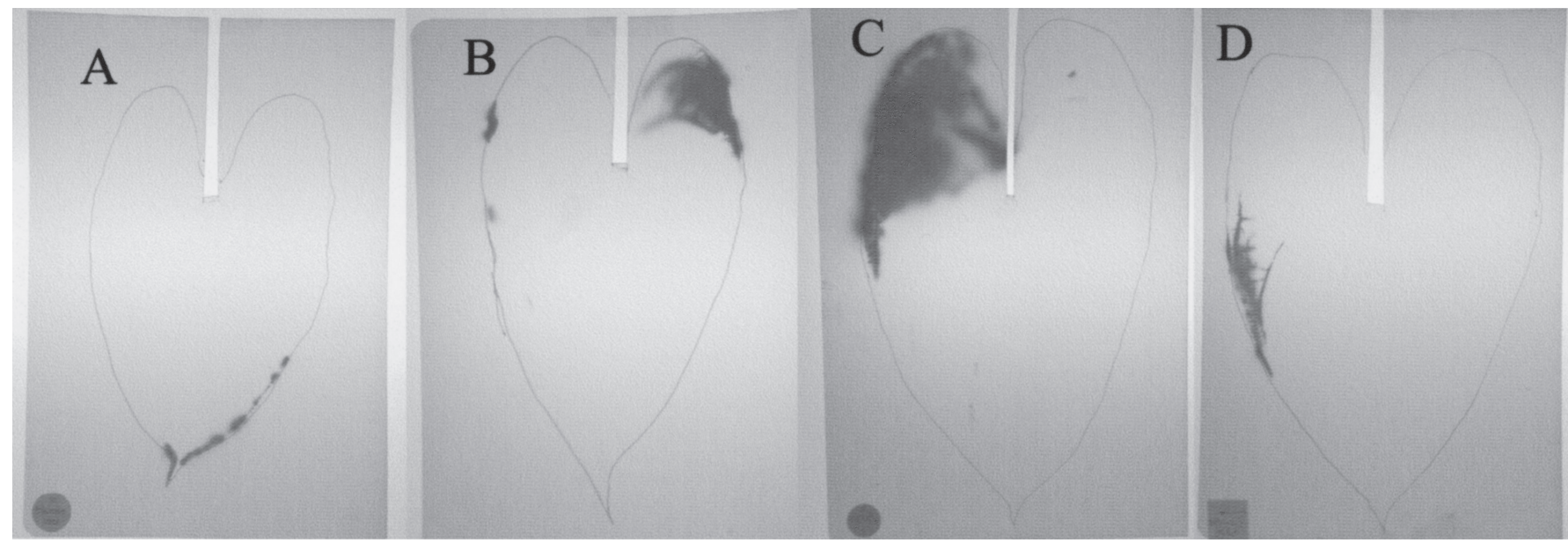

Fig. 4. Infection of Anthurium leaves with a bioluminescent strain of Xanthomonas axonopodis pv. dieffenbachiae as detected by X-ray film exposure at week 6 post-inoculation with $10^{5} \mathrm{cfu} / \mathrm{mL}$ Xad. Leaves are outlined by marker and bioluminescence appears as black on developed film. (A) Transgenic 'Paradise Pink' 1-4-5; (B) susceptible check 'Rudolph'; (C) Transgenic 'Tropic Flame' 1-16-3; (D) 'Tropic Flame' wild-type. 
in the leaf tissues compared with controls. Jaynes et al. (1993) also observed elevated disease symptoms in some tobacco plants transgenic for Shiva-1 when inoculated with Ralstonia solanacearum. They attributed this to a cell proliferation effect of peptides at low concentrations. In vitro, Peptidyl MIM 2L2, another synthetic cecropin analog, increased cell titers of Acholeplasma laidlawii $20 \%$ to $30 \%$ (Borth et al., 2001) at certain concentrations. These results taken together with the low level of Shiva-1 expression in 'Tropic Flame' 1-16 suggest that a sub-optimal level of Shiva-1 may actually increase disease susceptibility to anthurium blight in at least one genotype. An in vitro toxicity assay using Shiva-1 in buffer showed a dosage response of $\mathrm{Xad} \cdot$ lux growth, rather than a threshold response seen with other bacterial species endogenous to anthurium, with no increase in proliferation of $\mathrm{Xad} \cdot \mathrm{lux}$ at the lowest Shiva- 1 concentration tested $(0.125 \mu \mathrm{m}$; Fujii et al., 2002). Nevertheless, if it is correct that a lower level of expression of Shiva- 1 is the cause of the increased susceptibility to Xad.lux in the transgenic 'Tropic Flame' line, then one should test if down-regulation of a transgene, (i.e., under an environmental stress such as nematode infestation) could render an otherwise resistant transgenic cultivar to become more prone to systemic anthurium blight.

\section{Literature Cited}

Alvarez, A., D. Norman, and R. Lipp. 1991. Epidemiology and control of anthurium blight, p. 12-18, In: A.M. Alvarez, D.C. Deardorff, and K.B. Wadsworth (eds.). Proc.4th Hawaii Anthurium Industry Conf., Univ. Hawaii. Hawaii Inst. Trop. Agr. Human Resour. 04.06.91.

Alvarez, A., R. Lipp, and B. Bushe. 1989. Resistance of bacteria to antibiotics used for control of anthurium blight, p.11-13. In: J.A. Fernandez and W.T. Nishijima (eds.). Proc. 2nd Anthurium Blight Conf, Univ. Hawaii Hawaii Inst. Trop. Agr. Human Resour. 03.10.89.

Aragon, S.L., K. Chuang, and A.R. Kuehnle. 2004. An effective method for co-isolating nucleic acids from horticultural aroids. HortScience (in press).

Arce, P., M. Moreno, M. Gutierrez, M. Gebauer, P. Dell'Orto, H. Torres, I. Acuna, P., Oliger, A. Venegas, X. Jordana, J. Kalazich, and L. Holuique. 1999. Enhanced resistance to bacterial infection by Erwinia carotovora subsp. atroseptica in transgenic potato plants expressing the attacin or the cecropin SB-37 genes. Amer. J. Potato Res. 76:169-177.

Boman, H.G. 1991. Antibacterial peptides: Key components needed in immunity. Cell 65:205-207.

Boman, H.G., I. Faye, G.H. Gudmundsson, J.-Y. Lee, and D.-A. Lidholm. 1991. Cell-free immunity in Cecropia. A model system for antibacterial proteins. Eur. J. Biochem. 201:23-31.

Borth, W.B., V.P. Jones, D.E. Ullman, and J.S. Hu. 2001. Effects of synthetic cecropin analogs on in vitro growth of Acholeplasma laidlawii. Antimicrobial Agents and Chemotherapy 45:1894-1895.

Carlsson A., P. Engstrom, E.T. Palva, and H. Bennich. 1991. Attacin, an antibacterial protein from Hyalophora cecropia, inhibits synthesis of outer membrane proteins in Escherichia coli by interfering with omp gene transcription. Infection and Immunity 59:3040-3045.
Carlsson, A., T. Nystrom, H. de Cock, and H. Bennich 1998. Attacin — an insect immune protein — binds LPS and triggers the specific inhibition of bacteria outer-membrane protein synthesis. Microbiology 144:2179-2188.

Champagne, M.M. and A.R. Kuehnle. 2000. An effective method for isolating RNA from tissues of Dendrobium. Lindleyana 15:165-168.

Chen, F.C. and A.R. Kuehnle. 1996. Obtaining transgenic Anthurium through Agrobacteriummediated transformation of etiolated internodes. J. Amer. Soc. Hort. Sci. 121:47-51.

Dellaporta, S.L., J. Wood, and J.B. Hicks. 1983. A plantDNA minipreparation. version II. Plant Mol. Biol. Rpt. 1:19-21.

Denecke J., J. Botterman, and R. Deblaere. 1990. Protein secretion in plant cells can occur via a default pathway. Plant Cell 2:51-59.

Doyle J.J. and J.L. Doyle. 1990. Isolation of plant DNA from fresh tissue. Focus 12:13-15.

Florack, D., S. Allefs, R. Bollen, D. Bosch, B. Visser, and W. Stiekema. 1995. Expression of giant silkmoth cecropin B genes in tobacco. Transgenic Res. 4:132-141.

Fujii, T.M., A. Alvarez, R. Fukui, K. Obsuwan, and A.R. Kuehnle. 2002. Effect of transgenic anthuriums producing the Shiva-1 lytic peptide on beneficial bacteria. Phytopathology 92:S27.

Fukui, H., A.M. Alvarez, and R. Fukui. 1998. Differential susceptibility of anthurium cultivars to bacterial blight in foliar and systemic infection phases. Plant Dis. 82:800-806.

Fukui, R., H. Fukui, andA.M.Alvarez. 1999. Suppression of bacterial blight by a bacterial community isolated from the guttation fluids of anthuriums. App. Environ. Microbiol. 65:1020-1028.

Fukui, R., H. Fukui, R. McElhaney, S.C. Nelson, and A.M. Alvarez. 1996. Relationship between symptom development and actual sites of infection in leaves of anthurium inoculated with a bioluminescent strain of Xanthomonas campestris pv. dieffenbachiae. Appl. Environ. Microbiol. 62:1021-1028.

Hassan, M., S.L. Sinden, R.S. Kobayashi, R.O. Nordeen, and L.D. Owens. 1993. Transformation of potato (Solanum tuberosum) with a gene for an anti-bacterial protein, cecropin. Acta Hort. 336:127-130.

Hightower, R., C. Baden, E. Penzes, and P. Dunsmuir. 1994. The expression of cecropin peptide in transgenic tobacco does not confer resistance to Pseudomonas syringae pv. tabaci. Plant Cell Rpt. 13:295-299.

Huang, Y., R.O. Nordeen, M. Di, L.D. Owens, and J.H. McBeath. 1997. Expression of an engineered cecropin gene cassette in transgenic tobacco plants confers resistance to Pseudomonas syringae pv. tabaci. Phytopathology 87:494-499.

Hultmark, D. 1993. Immune reactions in drosophila and other insects: A model for innate immunity. Trends Genet. 9:178-183.

Janssen, K. 1995. Current protocols in molecular biology. vol. 2. John Wiley and Sons, New York.

Jaynes, J.M. 1993. Use for genes encoding novel lytic peptides and proteins that enhance microbial disease resistance in plants. Acta Hort. 336:33-39.

Jaynes, J.M., K.G. Xanthopoulos, L. Destefano-Beltran, and J.H. Dodds. 1987. Increasing bacterial disease resistance in plants utilizing antibacterial genes from insects. BioEssays 6:263-270

Jaynes, J.M., P. Nagpala, L. Destefano-Beltran, J.H. Hong, J. Kim, T. Denny, and S. Cetiner. 1993. Expression of a cecropin B peptide analog in transgenic tobacco confers enhanced resistance to bacterial wilt caused by Pseudomonas solanacearum. Plant Sci. 89:43-53.
Kamemoto, H. and A.R. Kuehnle. 1996. Breeding anthuriums in hawaii. Univ. Hawaii Press, Honolulu.

Ko, K., J.L. Norelli, J.-P. Reynoird, H.S. Aldwinckle, and S.K. Brown. 2002. T4 lysozyme and attacin genes enhance resistance of transgenic 'Galaxy' apple against Erwinia amylovora. J. Amer. Soc. Hort. Sci. 127:515-519.

Ko, K., J.L. Norelli, J. Reynoird, E. BoresjzaWysocka, S.K. Brown, and H.S. Aldwinckle. 2000. Effect of untranslated leader sequence of AMV RNA 4 and signal peptide of pathogenesisrelated protein $1 \mathrm{~b}$ on attacin gene expression, and resistance to fire blight in transgenic apple. Biotechnol. Lett. 22:373-381.

Kuehnle, A.R., F.-C.Chen, and N. Sugii. 1995. Novel approaches for genetic resistance to bacterial pathogens in flower crops. HortScience 30:456-461.

Kuehnle, A.R., N. Sugii, F.-C. Chen, N. Kuanprasert, R. Fukui, and A. Alvarez. 1996. Peptide biocides for engineering bacterial blight resistance to floral Anthurium. In Vitro Cell. Dev. Biol. 32:72A.

Kuehnle, A.R., F.C. Chen, and N.C. Sugii. 2001. Transgenic Anthurium, p. 3-15. In: Y.P.S. Bajaj (ed.). Biotechnology in agriculture and forestry. vol. 48. Transgenic crops. Springer Verlag, Berlin.

Li, Z., S. Jayasankar, and D.J. Gray. 2001. An improved enzyme-linked immunoabsorbent assay protocol for the detection of small lytic peptides in transgenic grapevines (Vitis vinifera). Plant Mol. Biol. Rpt. 19:341-351.

Nishijima, W.T. 1988. Anthuriumblight: an overview, p. 6-8.In:A.M.Alvarez (ed.).Proc. 1st Anthurium Blight Conf. Univ. Hawaii Inst. Trop. Agr. Human Resour. 02.04.88.

Norelli, J.L., H.S. Aldwinckle, L. Destefano-Beltran, and J.M. Jaynes. 1994. Transgenic 'Malling 26' apple expressing the attacin E gene has increased resistance to Erwinia amylovora. Euphytica 77:123-128.

Norman, D. and A. Alvarez. 1989. A rapid method for presumptive identification of Xanthomonas campestris pv. dieffenbachiae and other xanthomonads. Plant Dis. 73:654-658.

Norman, D.J. and A.M. Alvarez. 1996. Monitoring the spread of Xanthomonas campestris pv. dieffenbachiae introduced from symptomless anthurium cuttings into production fields. J. Amer. Soc. Hort. Sci. 121:582-285.

Owens, L.D. and T.M. Heutte. 1997. A single amino acid substitution in the antimicrobial defense protein cecropin B is associated with diminished degradation by leaf intercellular fluid. Mol. Plant Microbe Interact. 10:525-528.

Reynoird, J.P., F. Mourgues, J. Norelli, H.S. Aldwinckle, M.N. Brisset, and E. Chevreau. 1999. First evidence for improved resistance to fire blight in transgenic pear expressing the attacin E gene from Hyalophora cecropia. Plant Sci. 149:23-31.

Sambrook, J. and D.W. Russell. 2001. Molecular cloning_A laboratory manual. 3rd ed. Cold Spring Harbor Laboratory Press, Cold Spring Harbor, N.Y.

Sathyanarayana, N., R. Reddy, and R.L. Rajak. 1998. Interception of Xanthomonas campestris pv. dieffenbachiae on anthurium plants from the Netherlands. Plant Dis. 82:262.

Sharma, A., R. Sharma, M. Imamura, M. Yamakawa, and H. Machii. 2000. Transgenic expression of cecropin $\mathrm{B}$, an antibacterial peptide from Bombyx mori, confers enhanced resistance to bacterial leaf blight in rice. FEBS Lett. 484:7-11. 